\title{
PENINGKATAN KETERAMPILAN MENULIS TEKS BERITA DENGAN MODEL KOOPERATIF JIGSAW PADA SISWAKELAS VIII-B SMP NEGERI 1 PANCURBATU
}

Oleh:

\author{
Ester Hutasoit ${ }^{1)}$, Petrus Purwanto ${ }^{2)}$, dan Ermina Waruw ${ }^{3)}$ \\ Universitas Prima Indonesia, Medan. ${ }^{1,2,3)}$
}

\author{
E-Mail: \\ estrehts@gmail.com 1), \\ petruspurwanto59@gmail.com $^{2)}$,
}

\begin{abstract}
The ability in writing news text is a competence that must be achieved in KD 4.2 that present information data in the form of oral and written news considering the structure, elements and language. The purpose of the study is to improve news text writing skills by using the cooperative jigsaw model for students in class VIII-B of Pancurbatu 1 Public Middle School. Research method used is Classroom Action Research (CAR). Based on the results of class action research that has been carried out in 2 cycles, it can be seen from the activities of students in the learning process that their achievement was increasing in each cycle. In the first cycle the completeness of the test is $42,3 \%$. In cycle II it has increased, namely classical completeness as many as $84,61 \%$. So, it can be concluded that the increase in classical completeness is $42.31 \%$. Based on the results of class action research, using the two cycles with the cooperative jigsaw model, can improve news writing skills for students of class VIIIB of SMP Negeri 1 Pancurbatu Academic Year 2018/2019.
\end{abstract}

Keywords: Ability, Writing, Teka, News, Cooperative Jigsaw.

\section{PENDAHULUAN}

Kegiatan menulis merupakan bagian yang tak terpisahkan dalam seluruh proses belajar yang dialami oleh siswa. Karena kegiatan menulis mempunyai banyak keuntungan, yaitu dengan menulis kita dapat lebih menggali kemampuan dan potensi diri kita, melalui kegiatan menulis kita dapat mengembangkan berbagai gagasan. Kita terpaksa bernalar, menghubung-hubungkan serta membandingkan fakta-fakta yang mungkin tidak pernah kita lakukan jika kita tidak menulis. Kegiatan menulis memaksa kita lebih banyak menyerap, mencari, serta menguasai informasi sehubungan dengan topik yang kita tulis.

Berdasarkan pengamatan penulis selama PPL dan wawancara dengan guru Bahasa Indonesia kelas VIII-B SMP Negeri 1 Pancurbatu, masih banyak siswa yang belum terampil dalam menulis. Hal tersebut dikarenakan pembelajaran menulis lebih banyak disajikan dalam bentuk teori, tidak banyak melakukan praktik menulis. Keadaan dilapangan juga menunjukkan bahwa kemampuan siswa dalam menerima dan membangun pengetahuan yang baru dan pengalamannya sesuai materi pembelajaran masih rendah. Serta guru 
hanya memberikan penugasan atau latihan kepada siswa tanpa menggunakan media ataupun model dalam pembelajaran karena kurangnya ide dalam menemukan metode yang sesuai dengan konteks menulis. Dan mengakibatkan siswa merasa bosan dengan keterampilan menulis sehingga siswa kurang dalam minat menulis dan kurang dalam membentuk imajinasi. Hasil demikian disebabkan kurangnya motivasi siswa dalam belajar Bahasa Indonesia karena belum menggunakan media dan model pembelajaran yang memudahkan siswa untuk menulis.

Peneliti mendapatkan kesimpulan bahwa proses pembelajaran yang dilakukan guru cenderung ceramah dalam menyampaikan materi kepadasiswanya maka dari itu, kemampuan siswa dalam hal menulis belum memenuhi harapan guru dan belum mencapai pencapaian KKM yang telah ditentukan sekolah yaitu 70 .

Model pembelajaran yang dapat meningkatkan keterampilan menulis teks berita, salah satunya melalui model kooperatif jigsaw, Model pembelajaran jigsaw atau yang disebut juga Model Tim Ahli adalah teknik pembelajaran yang memusatkan perhatian pada kemampuan penguasaan materi pelajaran tertentu secara spesifik. Ibrahim, dkk (2000) berpendapat, model kooperatif jigsaw bertujuan untuk memperbaiki prestasi siswa. Jadi, dapat disimpulkan bahwa model kooperatif jigsaw ini didesain untuk meningkatkan rasa tanggung jawab siswa terhadap pembelajarannya sendiri dan juga pembelajaran orang lain.

Teks berita merupakan pemberitahuan tentang kejadian atau peristiwa yang telah terjadi dan merupakan sebuah fakta yang menarik perhatian semua orang.Berdasarkan pengertian tersebut maka dapat disimpulkan bahwa berita merupakan sebuah informasi yang menyangkut sebuah peristiwa atau kejadian yang aktual yang benar-benar terjadi dan dapat dibuktikan kebenarannya yang disiarkan oleh media massa.Melalui pembelajaran teks berita siswa diharapkan terampil dalam menulis teks berita.

\section{METODE PELAKSANAAN}

\section{Tempat dan Waktu}

Penelitian ini dilaksanakan di SMP Negeri 1 Pancurbatu kelas VIII-B Tahun Pembelajaran 2018/2019

\section{Pendekatan Penelitian}

Pendekatan penelitian merupakan cara ilmiah untuk mendapatkan data dengan tujuan dan kegunaan tertentu. Penelitian ini dilakukan dengan menggunakan Penelitian Tindakan Kelas (PTK).

\section{Subjek dan Objek Penelitian}

Subjek penelitian ini adalah siswa kelas VIII-B SMP Negeri 1 Pancurbatu Tahun Pembelajaran 2018/2019 yang berjumlah 26 siswa.

Objek penelitian ini adalah penerapan model pembelajaran kooperatif jigsaw untuk meningkatkan keterampilan menulis teks berita pada siswa kelas VIIIB SMP Negeri 1 Pancurbatu 2018/2019.

\section{Data dan Sumber Data}

Data adalah segala fakta dan angka yang dapat dijadikan bahan untuk menyusun suatu informasi serta materi mentah yang membentuk semua laporan penelitian. Adapun data yang digunakan dalam penelitian ini adalah kualitatif dan kuantitatif. Pengambilan data dilakukan di 
ruangan kelas VIII-B SMP Negeri 1

Pancurbatu tahun pelajaran 2018/2019.

Sumber data diperoleh dari tempat penelitian yang sudah ditentukan atau mendapat perlakuan tindakan penelitian yakni di kelas VIII-B SMP Negeri 1 Pancurbatu yang berupa informasi dari guru dan siswa kelas VIII-B melalui hasil wawancara, hasil tes belajar siswa pada pokok pembahasan teks berita pada mata pelajaran Bahasa Indonesia melalui model kooperatif jigsaw.

\section{Teknik Pengumpulan Data}

1. Wawancara

Wawancara atau interviewadalah suatu metode atau cara yang digunakan untuk mendapatkan jawaban dari responden dengan jalan Tanya jawab sepihak.

2. Observasi Pengamatan

Observasi adalah kegiatan pengamatan (pengambilan data) untuk memotret seberapa jauh efek tindakan telah mencapai sasaran.

3. Tes

Menurut Arikunto (2013: 193) tes adalah serentetan pertanyaan atau latihan serta alat lain yang digunakan untuk mengukur keterampilan, pengetahuan inteligensi kemampuan atau bakat yang dimiliki oleh individu atau kelompok.

4. Dokumentasi

Arikunto (2014:201) menjelaskan bahwa dokumentasi berasal dari kata dokumen, yang artinya barang-barang tertulis seperti bukubuku, peraturan, catatan harian. Dokumentasi bisa berbentuk tulisan, gambar, atau karya-karya dari seseorang.

\section{Indikator Kinerja}

Indicator kinerja yaitu tolak ukur untuk mengukur dan menentukan keberhasilan yang ditentukan oleh SMP Negeri 1 Pancurbatu adalah sebagai berikut: "Apabila nilai kriteria ketuntasan minimal (KKM) keterampilan menulis dalam teks berita $\geq 70$ dan nilai kriteria ketuntasan klasikal (KKK) 75\% dari jumlah siswa”.

\section{HASIL DAN PEMBAHASAN}

Penelitian ini akan membahas tentang peningkatan pembelajaran penelitian dalam dua siklus. Proses pembelajaran pada penelitian ini yang sudah dilaksanakan peneliti dengan menerapkan model jigsaw untuk memperbaiki hasil menulis teks berita pada siswa kelas VIII-B SMP Negeri 1 Pancurbatu Tahun Pelajaran 2018/2019 telah meningkat. Hasil penelitian ini terlihat dari penilaian tes yang diberikan kepada siswa untuk dikerjakan di setiap tahap-tahap kegiatan pembelajaran yang telah dilakukan penelitian yaitu siklus I dan siklus II.

\section{Tabel 1}

\section{Hasil Keterampilan Menulis Teks Berita Siklus I}

No Kualifikasi Abjad Siklus Persentase Nilai

$\begin{array}{lllll}1 & 90-100 & \text { A } & 1 & 3,84 \% \\ 2 & 80-89 & \text { B } & 2 & 7,70 \% \\ 3 & 70-79 & \text { C } & 8 & 30,76 \% \\ 4 & 60-69 & \text { D } & 10 & 38,46 \% \\ 5 & \leq 59 & \text { E } & 5 & 19,23 \%\end{array}$

Pada tabel berikut dapat dijelaskan bahwa siswa yang mempunyai 
kemampuan baik sekali dengan nilai (90100) dalam menulis teks berita berjumlah 1 siswa (3,84\%), yang mempunyai kemampuan baik dengan nilai (80-89) dalam menulis teks berita berjumlah 2 siswa $(7,70 \%)$, yang mempunyai kemampuan cukup dengan nilai (70-79) dalam menulis teks berita berjumlah 8 siswa $(30,76 \%)$, yang mempunyai kemampuan kurang dengan nilai (60-69) dalam menulis teks berita berjumlah 10 siswa $(38,46 \%)$, dan yang mempunyai kemampuan sangat kurang dengan nilai $(\leq 59)$ dalam menulis teks berita berjumlah 5 siswa $(19,23 \%)$, nilai akhir yang diperoleh secara individu siswa dikatakan telah ada peningkatan.

\section{Tabel 2}

\section{Hasil Keterampilan Menulis Teks Berita Siklus II}

\begin{tabular}{|c|c|c|c|c|}
\hline No & Kualifikasi & Siklus II & Siklus I & Persentase \\
\hline & Nilai & & & \\
\hline 1 & $90-100$ & A & 4 & $15,39 \%$ \\
\hline 2 & $80-89$ & B & 6 & $23,07 \%$ \\
\hline 3 & $70-79$ & $\mathrm{C}$ & 12 & $46,15 \%$ \\
\hline 4 & $60-69$ & $\mathrm{D}$ & 4 & $15,39 \%$ \\
\hline 5 & $\leq 59$ & $\mathrm{E}$ & 0 & $0 \%$ \\
\hline
\end{tabular}

Pada tabel berikut dapat dijelaskan bahwa siswa yang mempunyai kemampuan baik sekali dengan nilai (90100) dalam menulis teks berita berjumlah 4 siswa (15,39\%), yang mempunyai kemampuan baik dengan nilai (80-89) dalam menulis teks berita berjumlah 6 siswa $(23,07 \%)$, yang mempunyai kemampuan cukup dengan nilai (70-79) dalam menulis teks berita berjumlah 12 siswa $(46,15 \%)$, yang mempunyai kemampuan kurang dengan nilai (60-69) dalam menulis teks berita berjumlah 4 siswa $(15,39 \%)$, dan yang mempunyai kemampuan sangat kurang dengan nilai $(\leq 59)$ dalam menulis teks berita berjumlah 0 siswa $(0 \%)$, nilai akhir yang diperoleh secara individu siswa dikatakan telah ada peningkatan.

Telah terdapat peningkatan hasil keterampilan menulis teks berita karena mendapatkan kenaikan signifkan sebesar $42,31 \%$. Hal ini disebabkan siswa termotivasi untuk belajar, dan peningkatan pembelajaran ini menunjukkan bahwa pembelajaran menulis teks berita melalui model pembelajaran jigsaw merupakan cara yang sangat baik untuk meningkatkan keterampilan siswa dalam hal menulis. Peningkatan hasil keterampilan menulis berita dapat dilihat pada tabel berikut ini. 
Tabel 3

Rekapitulasi Peningkatan Hasil

Nilai Keterampilan Menulis Teks

berita pada Siswa Kelas VIII-B

SMP Negeri 1 Pancur Batu Pada

Siklus I dan Siklus II

\section{Rentang Nilai}

90-100

80-89

70-79

60-69

$\leq 59$

Jumlah Siswa

Nilai Tertinggi

Nilai Terendah

Persentase

Ketuntasan Klasikal

Dari tabel tersebut dapat dilihat pada siklus I siswa yang memperoleh nilai tertinggi dari 26 siswa yang mengikuti tes adalah dengan nilai 90 , sedangkan nilai terendah adalah 50. Pada siklus II siswa memperoleh nilai tertinggi adalah dengan nilai 95, sedangkan nilai terendah dengan nilai 65 . Hasil tes ini sudah memuaskan, karena terjadi peningkatan pada siklus II.

Pada siklus II persentase daya serap siswa mengalami peningkatan sebesar 42,31\%. Artinya, siswa sudah memahami secara baik materi pelajaran yang diajarkan dan siswa dapat menulis teks berita secara baik. Data tersebut menunjukkan bahwa terjadinya peningkatan pada setiap siklus. Ketuntasan belajar diperoleh memenuhi kriteria bahkan dapat dikatagorikan memuaskan, sebab kriteria ketuntasan minimum (KKM) secara klasikal SMP Negeri 1 Pancurbatu adalah 70 dan yang dicapai pada siklus II tersebut melebihi standar minimum 70 . Walaupun pada siklus I ketuntasan belajar siswa secara klasikal belum memuaskan, tetapi pada siklus II ketuntasan belajar secara klasikal sudah memuaskan, karena sudah mencapai target yang ditetapkan yaitu $75 \%$ siswa mendapatkan nilai 70 .

Tabel 4

Hasil Observasi Penilaian Afektif Siklus I (Aqib 2018: 68)

$\begin{array}{llll}\text { No } & \text { Aktivitas } & \text { Jumlah } \\ & & \text { Siswa } \\ \text { 1. } & \text { Ketepatan waktu } & 12 \\ \text { dalam } \\ \text { menyelesaikan }\end{array}$

2. Kerja sama $\quad 13 \quad 50$

3. Tanggung jawab $12 \quad 46$

4. Minat terhadap $17 \quad 65$ materi

5. Keaktifan dalam $16 \quad 61$ diskusi

6. Mampu $\quad 5 \quad 19$

mengungkapkan pendapat

7. Menghargai/ $\quad 10 \quad 38$ menghormati pendapat orang lain

8. Menggunakan tata $3 \quad 11$ bahasa dalam menjawab pertanyaan

9. Keseriusan dalam 5 19 menelaah soal

$\begin{array}{lll}10 & \text { Mampu } & 5\end{array}$ mendeskripsikan materi yang dibahas

Dalam observasi aktivitas siswa keaktifan siswa hanya $37 \%$ yang memenuhi kriteria, dapat disimpulkan bahwa kegiatan keaktivan siswa belum mencapai $75 \%$ untuk ketuntasan klaksikal. 
Sedangkan untuk penilaian keterampilan diperoleh ketuntasan belajar sebesar 42,3\%. Maka dapat dikatakan siklus I tidak berhasil.

\section{Tabel 5}

\section{Hasil Observasi Penilaian Afektif Siswa Siklus II (Aqib 2018: 68)}

\begin{tabular}{|c|c|c|}
\hline No & Aktivitas & $\begin{array}{l}\text { Jumlah } \\
\text { Siswa }\end{array}$ \\
\hline 1. & $\begin{array}{l}\text { Ketepatan waktu } \\
\text { dalam } \\
\text { menyelesaikan tugas }\end{array}$ & 23 \\
\hline 2. & Kerja sama & 20 \\
\hline 3. & Tanggung jawab & 23 \\
\hline 4. & $\begin{array}{l}\text { Minat } \quad \text { terhadap } \\
\text { materi }\end{array}$ & 26 \\
\hline 5. & $\begin{array}{l}\text { Keaktifan } \\
\text { diskusi }\end{array}$ & 24 \\
\hline 6. & $\begin{array}{l}\text { Mampu } \\
\text { mengungkapkan } \\
\text { pendapat }\end{array}$ & 20 \\
\hline 7. & $\begin{array}{l}\text { Menghargai/ } \\
\text { menghormati } \\
\text { pendapat orang lain }\end{array}$ & 25 \\
\hline 8. & $\begin{array}{l}\text { Menggunakan tata } \\
\text { bahasa dalam } \\
\text { menjawab } \\
\text { pertanyaan }\end{array}$ & 19 \\
\hline 9. & $\begin{array}{l}\text { Keseriusan dalam } \\
\text { menelaah soal }\end{array}$ & 24 \\
\hline 10 & $\begin{array}{l}\text { Mampu } \\
\text { mendeskripsikan } \\
\text { materi yang dibahas }\end{array}$ & 24 \\
\hline
\end{tabular}

Dalam observasi aktivitas siswa siklus II diperoleh keaktifan sebesar $87 \%$, dapat disimpulkan bahwa kegiatan keaktivan siswa sudah berhasil karena sudah mencapai $\geq 75 \%$ untuk ketuntasan klaksikal. Sedangkan untuk ketuntasan belajar sebesar 84,61\%. Maka dapat dikatakan siklus II berhasil.
Dari hasil observasi tentang aktivitas guru pada siklus II diperoleh data bahwa guru telah melaksanakan pembelajaran sesuai dengan prosedur pembelajaran pada lembar observasi guru adalah (1)prapembelajaran, (2) kegiatan inti pembelajaran, (3) pendekatan model pembelajaran, (4) pemanfaatan sumber belajar, (5) penutup. Lalu inti penilai observer (guru dan peneliti) selama proses pembelajaran berlangsung terhadap siswa di kelas VIII-B SMP Negeri 1 Pancur Batupada lembar observasi siswa adalah aspek kegiatan siswa dalam keterampilan menulis teks berita. Bentuk penilaian pengamatannya dapat dilihat pada lembaran lampiran penelitian ini.

Berdasarkan data tersebut dapat dilihat peningkatan aktivitas belajar siswa pada siklus I dan siklus II. Yang berdampak pada proses dan hasil belajar, dengan menerapkan model pembelajaran jigsaw.

Dari analisis data dan hasil penelitian siklus I dan II diketahui bahwa terjadi peningkatan kualitas belajar dalam keterampilan menulis teks berita dengan menerapkan model jigsaw. Peningkatan ini terjadi pada aktivitas dan hasil tes akhir siswa secara keseluruhan.

Pada proses pembelajaran siklus I dan siklus II yang telah dilaksanakan dengan menerapkan model jigsaw dalam menulis teks berita yang bertujuan untuk melakukan perbaikan dari kondisi awal siswa pada kegiatan pembelajaran agar dapat mencapai target kriteria ketuntasan minimal $\geq 70$ dan ketuntasan klasikal siswa $\geq 75 \%$. Adapun hasilnya pada kegiatan pembelajaran siklus I yang peneliti lakukan di kelas VIII-B mendapatkan standar $\mathrm{KKM} \geq 70$ hanya 15 siswa 
mencapai $42,3 \%$. Siswa yang belum lulus mendapatkan nilai $\leq 70$ ada 11 siswa. Pada proses siklus I indikator keberhasilan pada penilaian ketuntasan klasikal siswa belum sesuai atau melampaui $\geq 75 \%$ sehingga dapat disimpulkan belum tercapai.

Melihat dari siklus I tersebut perlu dilakukan perbaikan dari permasalahan yang ada sehingga peneliti merencanakan perbaikannya dengan melakukan tindakan proses pembelajaran di siklus II agar pembelajaran menulis teks berita dapat meningkat sesuai nilai KKM pelajaran Bahasa Indonesia yaitu 70. Proses pembelajaran siklus II pun masih menggunakan model jigsaw. Siswa yang mendapatkan nilai $\geq 70$ mencapai 22 siswa $(84,61 \%)$. Sedangkan siswa yang belum lulus mendapatkan nilai $\leq 70$ adalah 4 siswa $(15,38 \%)$.

Berdasarkan penelitian yang telah dilakukan bahwa proses pembelajaran yang menerapkan model jigsaw dapat meningkatkan dalam menulis teks berita siswa kelas VIII-B SMP Negeri 1 Pancurbatu tahun pelajaran 2018/2019. Model jigsaw pada mata pelajaran Bahasa Indonesia dapat berperan penting untuk meningkatkan keterampilan siswa dalam menulis teks berita pada siswa kelas VIIIB SMP Negeri 1 Pancurbatu tahun pelajaran 2018/2019.

\section{KESIMPULAN DAN SARAN}

\section{Kesimpulan}

Berdasarkan hasil penelitian tindakan kelas yang telah dilaksanakan dalam dua siklus dengan menggunakan model jigsaw dalam pembelajaran menulis teks berita pada siswa kelas VIII SMP SMP Negeri 1 Pancurbatu dapat disimpulkan bahwa Peningkatan hasil pembelajaran dalam menulis teks berita dengan menerapkan model jigsaw telah meningkat. Pembelajaran siklus I yang peneliti lakukan di kelas VIII-B masih dibawah KKM. Pada siklus I ketuntasan klaksikal 42,3\%. Pada siklus II telah meningkat yaitu ketuntasan klasikal 84,61\%. Maka, dapat disimpulkan kenaikan ketuntasan klasikal nya adalah 42,31\%. Model jigsaw pada bidang studi Bahasa Indonesia dengan sub pokok pembahasan materi pembelajaran menulis teks berita siswa dapat mengatasi sifat jenuh dan siswa lebih bersemangat dalam proses pembelajaran pada siswa kelas VIII-B SMP Negeri 1 Pancurbatu tahun pelajaran 2018/2019.

\section{SARAN}

Berdasarkan kesimpulan hasil penelitian yang telah dipaparkan tersebut, peneliti memberikan beberapa saran sebagai berikut.

1. Untuk Guru

Guru bidang studi Bahasa Indonesia di kelas VIII SMP Negeri 1 Pancurbatu, disarankan dengan adanya penelitian ini secara bertahap dapat mengetahui model pembelajaran yang bervariasi. Salah satu model yang baik digunakan adalah model jigsaw.

2. Untuk Sekolah

Penelitian ini disarankan untuk pihak sekolah agar dapat memberikan sumbangan yang positif dalam pembelajaran Bahasa Indonesia khususnya pembelajaran menulis teks berita SMP Negeri 1 Pancurbatu. 


\section{DAFTAR PUSTAKA}

Aqib-Z, Amrullah-A. 2018. Penelitian

Tindakan Kelas. Yogyakarta: Andi

Aqib-Z. 2013. Model-Model, Media, dan Strategi Pembelajaran Kontekstual

(Inovatif).Bandung: Penerbit Yrama Widya

Barus, 2010. Jurnalistik Petunjuk Teknis Menulis Berita. Jakarta: Penerbit Erlangga

Dalman, 2010. Keterampilan Menulis. Bandar Lampung: UM Lampung

Tarigan, Henry Guntur. 2008. Menulis sebagai suatu Keterampilan Berbahasa. Bandung: PT. Percetakan Angkasa. 